\title{
Database of rainfall erosivity factor for 141 locations in Brazil.
}

Recebido: 28/11/2021 | Aceito: 12/12/2021 | Publicado: 20/12/2021 https://doi.org/10.53805/lads.v1i3.37

Roberto A. Cecílio ${ }^{* 1}$, João Paulo B. de Oliveira ${ }^{2}$, David Bruno de S. Teixeira ${ }^{3}$, Fernando F. Pruski ${ }^{3}$, Sidney S. Zanetti ${ }^{1}$

\section{ABSTRACT}

Soil erosion is a serious agricultural and environmental problem considered as a threat to sustainable development around the world. Rainfall is the primary cause of soil erosion, what leads the knowledge of its potential to cause soil erosion (rainfall erosivity - R-factor) to be a valuable tool for the design of land conservation best practices. As Brazil has a lack of information about rainfall erosivity, the present paper has determined the R-factor of 141 pluviographic stations distributed over Brazilian territory. Initially, erosive rainfalls were identified, and then the $\mathrm{El}_{30}$ erosivity index was used to obtain the rainfall erosivity values. Regression models for the estimation of rainfall erosivity using daily rainfall data were established based on the correlation between the monthly average values of erosivity and the modified Fournier index. Results showed that the annual rainfall erosivity in the Brazilian stations analyzed ranged from 368.7 to $16,850.6 \mathrm{MJ} \mathrm{mm} \mathrm{ha-1} \mathrm{h}^{-1}$ year ${ }^{-1}$. The results presented help to expand information about the spatial distribution of rainfall erosivity in Brazil, contributing to better conservation planning of land use.

Keywords: Erosion; Rainfall homogeneous zones; USLE; Modified Fournier index.

\section{PRIOR PUBLICATIONS}

OLIVEIRA, J. P. B. de, et al. Assessing the use of rainfall synthetic series to estimate rainfall erosivity in Brazil. CATENA, v. 171, p. 327-336, 2018. DOI: http://dx.doi.org/10.1016/j.catena.2018.07.031.

\footnotetext{
${ }^{1}$ Federal University of Espírito Santo, Forest and Wood Sciences Department, Jerônimo Monteiro, Brasil. roberto.cecilio@ufes.br.

2 Instituto Federal do Espírito Santo, Campus Alegre, Alegre, Brasil.

${ }^{3}$ Federal University of Viçosa, Agricultural Engineering Department, Viçosa, Brasil.
} 


\section{DATA IMPORTANCE}

- Database has enormous potential to be applied for soil erosion and soil conservation studies;

- Largely increases the availability of rainfall erosivity (R-factor) values for Brazil;

- Many of the data are still unknown and consists in original data to Brazilian researches (specially at SemiArid Region);

- Provides a better spatial distribution of known Brazilian stations R-factor's values;

- Presents a set of still unknow regression equations to predict R-factor from monthly rainfall amounts.

\section{MATERIALS AND METHODS}

Rainfall erosivity was calculated for 141 Brazilian raingauge stations (Fig. 1) using daily rainfall pluviographs. All the raingauge stations belong to Brazilian Institute of Meteorology (INMET). To better present and discuss the results later, Brazilian territory was divided into homogeneous zones according to rainfall characteristics (BAENA et al., 2005), as also showed in Figure 1. The number of years with daily pluviographs varied from 3 to 11 in Zone B1; 6 to 14 in Zone B2; 3 to 10 in Zone B3; 10 to 27 in Zone $B 4 ; 12$ to 22 in Zone B5; 10 to 31 in Zone B6 and was equal to 5 years in Zone B7.

Figure 1 - Spatial distribution of Brazilian raingauge stations and division of Brazilian area into homogeneous zones according to rainfall characteristics (BAENA et al., 2005).

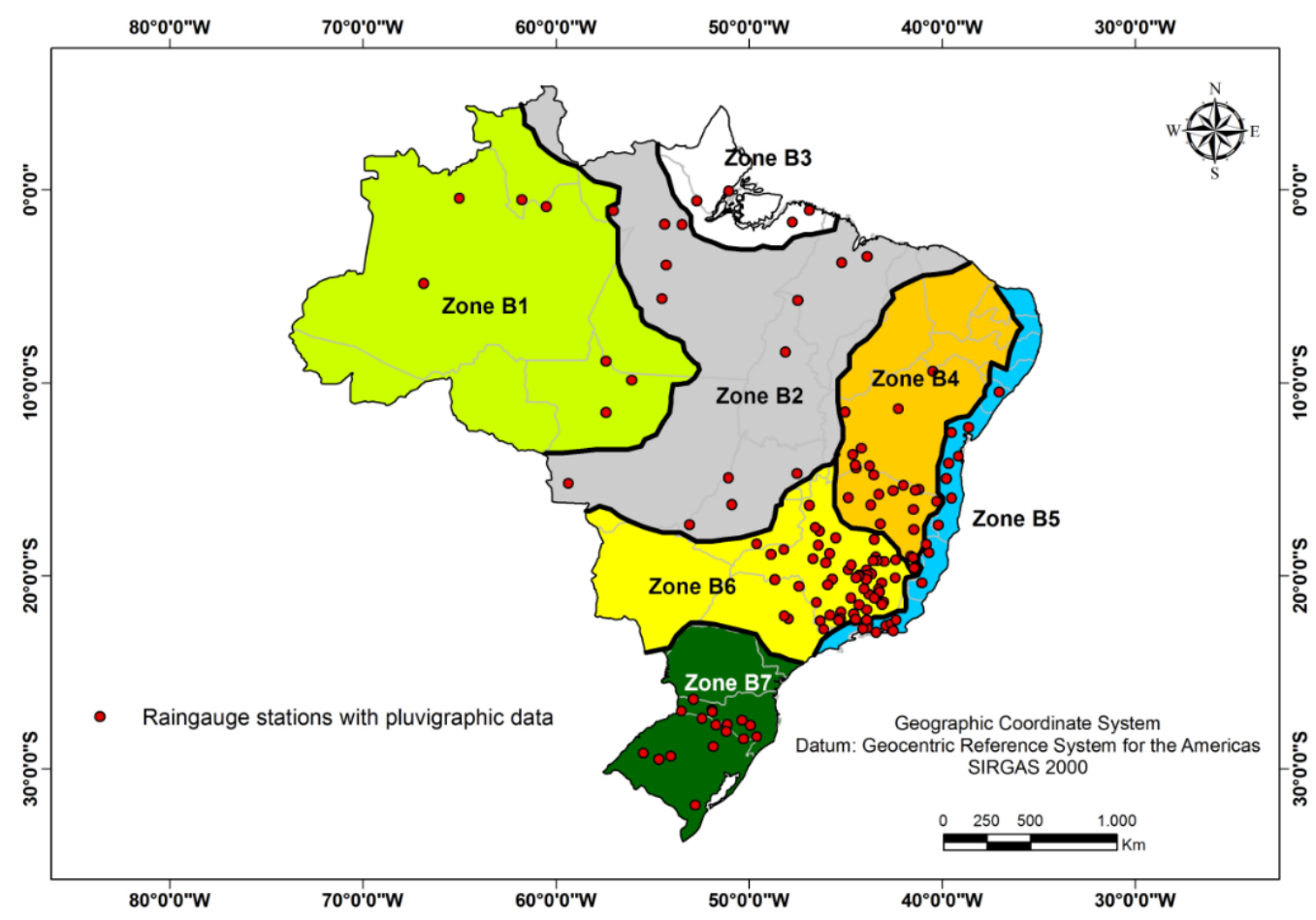

In order to proceed the calculation of the Rfactor, all the isolated rainfalls must be first classified as either erosive or nonerosive. The erosive events were all the individual rainfall with depth equal or higher than $10 \mathrm{~mm}$, or that one with depth lower than $10 \mathrm{~mm}$, but with a 15minute depth equal or greater than $6 \mathrm{~mm}$ (CABEDA, 1976).

Kinetic energy (KE) of each erosive rain was computed individually by the equation 1 (FOSTER 
et al., 1981) when erosive rainfall intensity was equal to or lower than $76 \mathrm{~mm} \mathrm{~h}^{-1}$. KE of erosive rains with greater intensities was assumed to be equal to $0.283 \mathrm{MJ} \mathrm{ha}^{-1} \mathrm{~mm}^{-1}$ (FOSTER et al., 1981).

$K E=0.119+0.0873 \log 1$

where $\mathrm{KE}$ is the kinetic energy, $\mathrm{MJ} \mathrm{ha}{ }^{-1} \mathrm{~mm}^{-1}$; and $\mathrm{I}$ is rainfall intensity, $\mathrm{mm} \mathrm{h}^{-1}$.

The erosivity index (EI30) (WISCHMEIER; SMITH, 1958) for each rainfall event was calculated as the product of total kinetic energy (KE) and the maximum $30 \mathrm{~min}$ intensity (WISCHMEIER; SMITH, 1958). The total KE of each event was calculated using the one-minute time step. Monthly and annual values of the R-factor were determined as the sum of the El30 for all the individual rainfall events that occurred in one month or year. Then mean monthly and annual values for R-factor were computed average values for the number of years with measured data available to each station.

Due to the scarcity of raingauge stations with pluviographic data in Brazil, regression models for the estimation of rainfall erosivity using daily rainfall data were established. These models were based on the correlation between the monthly average values of erosivity and the modified Fournier index (MFI). The MFI, obtained from Equation 2, relates the mean monthly rainfall and the mean annual rainfall and was used as an independent variable to obtain the erosivity estimation models. Only models that presented values of coefficient of determination $\left(R^{2}\right)$ for the regression above 0.70 were considered representative. Models with $R^{2}<0.70$ were omitted from the results.

$M F I_{i}=\frac{\left(R_{i}\right)^{2}}{R_{a}}$

where $\mathrm{MFI}_{\mathrm{i}}$ is the modified Fournier index for the month $\mathrm{i} ; \mathrm{R}_{\mathrm{i}}$ is the mean monthly rainfall in month $\mathrm{i}, \mathrm{mm}$; and $R_{a}$ is the mean annual rainfall, $\mathrm{mm}$.

\section{DATA DESCRIPTION}

The tables of the supplementary database presents monthly and annual R-factors calculated with pluviographic measured data to the stations located on Zones B1 to B7.

Zone B1 can be classified as the one that presents the higher average $\mathrm{R}$-factor values in Brazil. The average erosivity ( \pm standard deviation) observed was $12,124 \pm 1,489 \mathrm{MJ} \mathrm{mm} \mathrm{ha}^{-1} \mathrm{~h}^{-1}$ year ${ }^{1}$. The only previously known R-factors (calculated with pluviographic data) on the same region are the ones of Manaus station (14,129 MJ mm ha-1 $\mathrm{h}^{-}$ ${ }^{1}$ year $^{-1}$ ) (OLIVEIRA JÚNIOR; MEDINA, 1990) and Vera station $\left(15,965 \mathrm{MJ} m \mathrm{~m} \mathrm{ha}^{-1} \mathrm{~h}^{-1}\right.$ year $\left.^{-1}\right)$ (OLIVEIRA; WENDLAND; NEARING, 2012), that are close to the $\mathrm{R}$-factor calculated in the present paper.

The average erosivity of Zone B2 $(10,144 \pm$ 2,340 MJ mm ha ${ }^{-1} \mathrm{~h}^{-1}$ year $^{-1}$ ) is only lower than average R-factor of Zone B1 and quite similar to Zone $B 3$ average. A review of scientific papers that calculated rainfall erosivity on this Zone (DIAS; SILVA, 2003; OLIVEIRA; WENDLAND; NEARING, 2012; SILVA et al., 1997) showed R-factor ranging from 6,641 to $14,756 \mathrm{MJ} \mathrm{mm} \mathrm{ha}^{-1} \mathrm{~h}^{-1}$ year $^{-1}$.

Zone B3, on the mouth of Amazon basin, presents $R$-factor average values are about 10,270 $\pm 793 \mathrm{MJ} \mathrm{mm} \mathrm{ha}^{-1} \mathrm{~h}^{-1}$ year $^{-1}$. Bragança city, on this Zone, has calculated R-factor equals to $12,351 \mathrm{MJ}$ $\mathrm{mm}$ ha $^{-1} \mathrm{~h}^{-1}$ year $^{-1}$ (OLIVEIRA; WENDLAND; NEARING, 2012).

On Zone B4 were observed the lower average $\mathrm{R}$-factor values $\left(1,089 \pm 267 \mathrm{MJ} \mathrm{mm} \mathrm{ha}^{-1} \mathrm{~h}^{-1}\right.$ year $\left.{ }^{1}\right)$. Literature review shows only one published research related to $\mathrm{R}$-factor on this Zone, referring to Pernambuco State (CANTALICE et al., 2009). It shows R-factors ranging from 1,672 to $3,480 \mathrm{MJ}$ $\mathrm{mm} \mathrm{ha}{ }^{-1} \mathrm{~h}^{-1}$ year $^{-1}$, which are higher than the ones calculated in the present paper. However, all the stations presented on Cantalice et al. (2009) belongs to the northern site of Zone B4, where 
rainfall amounts are greater (MARENGO, 1995). Besides, the results of the present paper were calculated using precipitation dataset with 10 to 27 years in extension; meanwhile, Cantalice et al. (2009) used dataset only with 5 to 11 years in extension. However, concerning to Zone B4 Rfactors values, it can be observed that they were similar to R-factors of other arid or semi-arid regions worldwide. For example: Nigeria $-1,985$ MJ mm ha ${ }^{-1} h^{-1}$ year $^{-1}$ (DELWAULLE, 1973); Kenia MJ mm ha-1 $\mathrm{h}^{-1}$ year $^{-1}$ (MOORE, 1979); Cape Verde - 2,000 MJ mm ha-1 $\mathrm{h}^{-1}$ year $^{-1}$ (MANNAERTS; GABRIELS, 2000); Chile - below $500 \mathrm{MJ} \mathrm{mm} \mathrm{ha}^{-1} \mathrm{~h}$ 1 year $^{-1}$ (BONILLA; VIDAL, 2011); and Canary Islands (Spain) - 640 MJ mm ha ${ }^{-1} \mathrm{~h}^{-1}$ year $^{-1}$ (RODRÍGUEZ et al., 2004).

The higher variability on R-factor occurred at Zone $\mathrm{B} 5$, which presented average value equals to $5,438 \pm 2,020 \mathrm{MJ} \mathrm{mm} \mathrm{ha}^{-1} \mathrm{~h}^{-1}$ year $^{-1}$. Lower values occurred on Northern site while the higher ones took place on Southern site. Other papers (CANTALICE et al., 2009; CARVALHO et al., 2005; GONÇALVES et al., 2006; MACHADO et al., 2008; MARTINS et al., 2010) found similar R-factors; even to Northern site, on Pernambuco State (ranging from 3,212 to $6,325 \mathrm{MJ} \mathrm{mm} \mathrm{ha}^{-1} \mathrm{~h}^{-1}$ year $\left.{ }^{1}\right)$; or to Southern site on Rio de Janeiro and Espírito Santo States (between 4,118 and 15,806 MJ mm ha- ${ }^{-1}{ }^{-1}$ year $^{-1}$ ).

Average rainfall erosivity of Zone $\mathrm{B} 6$ was about $7,022 \pm 1,092 \mathrm{MJ} \mathrm{mm} \mathrm{ha}^{-1} \mathrm{~h}^{-1}$ year $^{-1}$. Similarly, other researches on the same Zone (OLIVEIRA et al., 2012; ROQUE; CARVALHO; PRADO, 2001; SANTOS et al., 2012) have found R-factor ranging from 5,056 e 18,646 MJ mm ha-1 $\mathrm{h}^{-1}$ year $^{-1}$, with higher values associated with the Western site, not covered by any stations of the present paper.

The rainfall erosivity values of Zone B7 were quite similar to Zone $B 6$, presenting average value equals to $6,681 \pm 1,100 \mathrm{MJ} \mathrm{mm} \mathrm{ha}^{-1} \mathrm{~h}^{-1}$ year $^{-1}$. These values are close to the ones calculated on several stations of the Zone on other papers (BAZZANO; ELTZ; CASSOL, 2007, 2010; BERTOL, 1994; CASSOL et al., 2007, 2008; ELTZ; CASSOL;
PASCOTINI, 2011; HICKMANN et al., 2008; MAZURANA et al., 2009; OLIVEIRA; WENDLAND; NEARING, 2012), that ranged from 5,135 to 11,217 MJ mm ha ${ }^{-1} h^{-1}$ year ${ }^{-1}$.

Regarding the regression models established to estimate rainfall erosivity using daily rainfall data, a significant correlation $\left(R^{2}>0.70\right)$ was found for 89 of the 141 rainfall gauges used. Unlike the other zones, there were no rainfall gauges that presented a significant correlation for Zone B7, so no regression model was established for this zone.

These regression models become important since they are an easy-to-apply alternative for estimating rainfall erosivity on a local scale, or for a specific dataset. Thus, the models proposed in this study aim to update and expand the spatial availability of rainfall erosivity values in Brazil.

As the availability of calculated R-factor in Brazil is considered small (OLIVEIRA; WENDLAND; NEARING, 2012), it can be considered that the presented data contributes to increasing the Brazilian database. Besides, as also pointed out by Oliveira et al. (2012), the previous papers concentrated the determination of $\mathrm{R}$-factor on the stations of the south and southeast regions (Zones B6 and B7), with only a few studies in other zones. The R-factor presented in this paper can be considered as a great increase in the availability of information to Zones B1, B2, B3, B4 and North part of Zone B5 (Brazilian North, Northeast, and Central-West Regions) where the data are scarce.

In the present paper, the extension of pluviographic data used to calculate R-factor of some raingauge stations is still less than the recommended standard for the application of RUSLE (20 years of data). However, hydrological and meteorological information is very scarce or frequently difficult to access in Brazil (OLIVEIRA et al., 2012). In that way, the authors of the present paper must agree with Oliveira et al. (2012) that recommended the maintenance of the existing raingauge stations and also the establishment of new stations. 


\section{Database}

File database.xlsx

Column A: Homogeneous rainfall zone

Column B: State

Column C: Station Code

Column D: Station location (city)

Column E: Station latitude (decimal

degree)

Column F: Station longitude (decimal degree)

Column G: January's rainfall erosivity (MJ $\mathrm{mm} \mathrm{ha}^{-1} \mathrm{~h}^{-1}$ month $^{-1}$ )

Column H: February's rainfall erosivity (MJ $\mathrm{mm} \mathrm{ha}^{-1} \mathrm{~h}^{-1}$ month $^{-1}$ )

Column I: March's rainfall erosivity (MJ mm ha $^{-1} \mathrm{~h}^{-1}$ month $^{-1}$ )

Column J: April's rainfall erosivity (MJ mm ha $^{-1} \mathrm{~h}^{-1}$ month $^{-1}$ )

Column K: May's rainfall erosivity (MJ mm ha $^{-1} \mathrm{~h}^{-1}$ month $^{-1}$ )
Column L: June's rainfall erosivity (MJ $\mathrm{mm} \mathrm{ha}^{-1} \mathrm{~h}^{-1}$ month $^{-1}$ )

Column M: July's rainfall erosivity (MJ $\mathrm{mm} \mathrm{ha}^{-1} \mathrm{~h}^{-1}$ month $^{-1}$ )

Column N: August's rainfall erosivity (MJ $\mathrm{mm} \mathrm{ha}^{-1} \mathrm{~h}^{-1}$ month $^{-1}$ )

Column O: September's rainfall erosivity (MJ mm ha ${ }^{-1} \mathrm{~h}^{-1}$ month $^{-1}$ )

Column P: October's rainfall erosivity (MJ $\mathrm{mm} \mathrm{ha}^{-1} \mathrm{~h}^{-1}$ month $^{-1}$ )

Column Q: November's rainfall erosivity (MJ mm ha-1 $\mathrm{h}^{-1}$ month $^{-1}$ )

Column R: December's rainfall erosivity (MJ mm ha-1 $\mathrm{h}^{-1}$ month $^{-1}$ )

Column S: Annual's rainfall erosivity - Rfactor (MJ mm ha ${ }^{-1} \mathrm{~h}^{-1} \mathrm{month}^{-1}$ )

Column T: Regression model for the estimation of rainfall erosivity

Column U: Determination coefficient for Column T's regression model.

\section{SUPPLEMENTARY MATERIALS}

Dataset: Zanetti et al_Dataset

\section{ACKNOWLEDGEMENTS}

This study was financed in part by the Coordenação de Aperfeiçoamento de Pessoal de Nível Superior Brasil (CAPES) - Finance Code 001; and, Conselho Nacional de Desenvolvimento Científico e Tecnológico Brasil (CNPq) - Finance Code 304916/2017-

\section{REFERENCES}

BAENA, L. G. N. et al. Software for Generating Synthetic Series of Climatic Data. Engenharia na Agricultura, v. 13, n. 3, p. 210-220, 2005.

BAZZANO, M. G. P.; ELTZ, F. L. F.; CASSOL, E. A. Erosivity, rainfall coefficient and patterns and return period in Quarai, RS, Brazil. Revista Brasileira de Ciência do Solo, v. 31, n. 5, p. 1205-1217, 2007. DOI: https://doi.org/10.1590/S0100-06832007000500036.

BAZZANO, M. G. P.; ELTZ, F. L. F.; CASSOL, E. A. Erosivity and hydrological characteristics of rainfalls in Rio Grande (RS, Brazil). Revista Brasileira de Ciência do Solo, v. 34, n. 1, p. 235-244, 2010. DOI: https://doi.org/10.1590/\$0100-06832010000100024.

BERTOL, I. Avaliação da erosividade da chuva na localidade de Campos Novos (SC) no período de 19811990. Pesquisa Agropecuária Brasileira, v. 29, n. 9, p. 1453-1458, 1994. 
BONILLA, C. A.; VIDAL, K. L. Rainfall erosivity in Central Chile. Journal of Hydrology, v. 410, n. 1-2, p. 126133, nov. 2011. DOI: https://doi.org/10.1016/j.jhydrol.2011.09.022

CABEDA, M. S. V. Computation of storm El value. West Lafayette: Purdue University, 1976.

CANTALICE, J. R. B. et al. Linhas Isoerosivas do Estado de Pernambuco - 1a aproximação. Revista Caatinga, v. 22, n. 2, p. 75-80, 2009.

CARVALHO, D. F. DE et al. Padrões de precipitação e índices de erosividade para as chuvas de Seropédica e Nova Friburgo, RJ. Revista Brasileira de Engenharia Agrícola e Ambiental, v. 9, n. 1, p. 7-14, mar. 2005. DOI: https://doi.org/10.1590/S1415-43662005000100002.

CASSOL, E. A. et al. Erosividade e padrões hidrológicos das chuvas de ljuí ( RS ) no período de 1963 a 1993. Revista Brasileira de Agrometeorologia, v. 15, n. 3, p. 220-231, 2007.

CASSOL, E. A. et al. Erosividade, padrões hidrológicos, período de retorno e probabilidade de ocorrência das chuvas em São Borja, RS. Revista Brasileira de Ciência do Solo, v. 32, n. 3, p. 1239-1251, jun. 2008.

DELWAULLE, J. C. Résultats de six ans d'observation sur l'érosion au Niger. Bois et Fôrets des Tropiques, v. 150, p. 15-36, 1973.

DIAS, A. S.; SILVA, J. R. C. A erosividade das chuvas em Fortaleza (CE): I - distribuição, probabilidade de ocorrência e período de retorno - $1^{\text {a }}$ aproximação. Revista Brasileira de Ciência do Solo, v. 27, n. 2, p. 335345, abr. 2003. DOI: https://doi.org/10.1590/S0100-06832003000200013.

ELTZ, F. L. F.; CASSOL, E. A.; PASCOTINI, P. B. Potencial erosivo e características das chuvas de Encruzilhada do Sul, RS. Revista Brasileira de Engenharia Agrícola e Ambiental, v. 15, n. 4, p. 331-337, abr. 2011. DOI: https://doi.org/10.1590/S1415-43662011000400001.

FOSTER, G. R. et al. Conversion of the universal soil loss equation to SI metric units. Journal of Soil and Water Conservation, v. 36, n. 6, p. 355-359, 1981.

GONÇALVES, F. A. et al. Índices e espacialização da erosividade das chuvas para o Estado do Rio de Janeiro. Revista Brasileira de Engenharia Agrícola e Ambiental, v. 10, n. 2, p. 269-276, jun. 2006.

HICKMANN, C. et al. Erosividade das chuvas em Uruguaiana, RS, determinada pelo índice El30, com base no período de 1963 a 1991. Revista Brasileira de Ciência do Solo, v. 32, n. 2, p. 825-831, abr. 2008. DOI: https://doi.org/10.1590/S0100-06832008000200036.

MACHADO, R. L. et al. Análise da erosividade das chuvas associada aos padrões de precipitação pluvial na região de Ribeirão das Lajes (RJ). Revista Brasileira de Ciência do Solo, v. 32, n. 1, p. 2113-2123, 2008.

MANNAERTS, C. M.; GABRIELS, D. Rainfall erosivity in Cape Verde. Soil and Tillage Research, v. 55, n. 3-4, p. 207-212, jun. 2000. DOI: https://doi.org/10.1016/S0167-1987(00)00104-5.

MARENGO, J. A. Interannual variability of deep convection over the tropical South American sector as deduced from ISCCP C2 data. International Journal of Climatology, v. 15, n. 9, p. 995-1010, set. 1995. DOI: https://doi.org/10.1002/joc.3370150906.

MARTINS, S. G. et al. Rainfall erosivity and rainfall return period in the experimental watershed of Aracruz. Revista Brasileira de Ciência do Solo, v. 34, p. 999-1004, 2010. DOI: https://doi.org/10.1590/S010006832010000300042.

MAZURANA, J. et al. Erosividade, padrões hidrológicos e período de retorno das chuvas erosivas de Santa Rosa (RS). Revista Brasileira de Engenharia Agrícola e Ambiental, v. 13, n. suplemento, p. 975-983, dez. 2009.

MOORE, T. R. Rainfall Erosivity in East Africa. Geografiska Annaler. Series A, Physical Geography, v. 61, n. 3/4, p. 147, 1979. DOI: https://doi.org/10.1080/04353676.1979.11879987.

OLIVEIRA, P. T. S. DE et al. Spatial variability of the rainfall erosive potential in the State of Mato Grosso do Sul, Brazil. Engenharia Agrícola, v. 32, n. 1, p. 69-79, 2012. 
OLIVEIRA, P. T. S. DE; WENDLAND, E.; NEARING, M. A. Rainfall erosivity in Brazil: A review. CATENA, v. 100, p. 139-147, 2012. DOI: https://doi.org/10.1016/j.catena.2012.08.006.

OLIVEIRA JÚNIOR, R. C.; MEDINA, B. F. A erosividade das chuvas em Manaus. Revista Brasileira de Ciência do Solo, v. 14, p. 235-239, 1990.

RODRÍGUEZ, A. R. et al. Forms of eroded soil organic carbon in andosols of the Canary Islands (Spain). Geoderma, v. 121, n. 3-4, p. 205-219, ago. 2004. DOI: https://doi.org/10.1016/j.geoderma.2003.11.009.

ROQUE, C. G.; CARVALHO, M. P.; PRADO, R. M. Fator erosividade da chuva de Piraju (SP): distribuição, probabilidade de ocorrência, período de retorno e correlação com o coeficiente de chuva. Revista Brasileira de Ciência do Solo, v. 25, n. 1, p. 147-156, mar. 2001.

SANTOS, R. S. DOS et al. Homogeneidade de séries climatológicas em Minas Gerais. Revista Brasileira de Engenharia Agrícola e Ambiental, v. 16, n. 12, p. 1338-1345, 2012. DOI: https://doi.org/10.1590/S141543662012001200011.

SILVA, M. L. N. et al. Rainfall erosivity indices in the Goiânia region, Goiás state, Brazil. Pesquisa Agropecuária Brasileira, v. 32, n. 10, p. 977-985, 1997.

WISCHMEIER, W. H.; SMITH, D. D. Rainfall energy and its relationship to soil loss. Transactions, American Geophysical Union, v. 39, n. 2, p. 285, 1958. DOI: https://doi.org/10.1029/TR039i002p00285. 